\title{
COMMENTS
}

\section{Give 'Em Enough Rope: States, Subdivisions and the Market Participant Exception to the Dormant Commerce Clause}

\author{
Barton B. Clark $\uparrow$
}

To protect in-state businesses from out-of-state competition, several states have enacted local preference statutes. These statutes require that a state's towns, cities or other subdivisions favor in-state businesses when they make certain purchases and sales. ${ }^{1}$ For example, Alaska requires schools receiving state funds to buy Alaskan agricultural products unless the products are more than seven percent more expensive than equivalent products from outof-state. ${ }^{2}$ Not surprisingly, out-of-state businesses unable to sell products to towns and cities in states with such local preference statutes feel discriminated against; they complain that such statutes violate the dormant Commerce Clause. ${ }^{3}$

The Supreme Court has not decided whether a state can impose a local preference on its subdivisions. A state cannot impose a local preference on private parties. ${ }^{4}$ But the state may prefer instate businesses-so long as it acts as a "market participant." A

† B.A. 1990, Harvard College; J.D. Candidate 1994, The University of Chicago.

1 By enacting a "preference statute," a political entity commits itself to prefer its own residents when making sales or purchases. By contrast, "local preference statutes" impose resident preferences on a state's political subdivisions.

${ }^{2}$ See Alaska Stat $\S 36.15 .050$ (Michie 1992).

- See Hughes v Alexandria Scrap Corp., 426 US 794, 802, 804-05 (1976).

- See Wyoming $v$ Oklahoma, 112 S Ct 789, 800-02 (1992) (rejecting an Oklahoma statute requiring that private electric utilities purchase at least $10 \%$ Oklahoma-mined coal).

- See South-Central Timber Development, Inc. v Wunnicke, 467 US 82, 93-95 (1984) (summarizing cases). As the Court noted, "if a State is acting as a market participant, rather 
state acts as a market participant when it buys and sells goods and thereby takes on attributes of a private business. ${ }^{6}$ In such cases, a state may freely "determine those with whom it will deal, and [] fix the terms and conditions upon which it will make needed purchases." Acting as market participants, states have, for example, made it more lucrative to sell scrap autos to in-state than to out-of-state processors ${ }^{8}$ and forced out-of-state customers for state-produced cement to wait until all in-state buyers were satisfied. ${ }^{9}$

Lower courts currently disagree over whether local preference statutes should be treated as instances of market participation or as instances of states impermissibly imposing a preference on autonomous entities. The Seventh Circuit voided an Illinois law requiring contractors on any public works project to hire only Illinois laborers, ${ }^{10}$ but the Third and Ninth Circuits have upheld similarlystructured laws as forms of market participation. ${ }^{11}$

This disagreement reflects an uncertainty about the market participant exception itself. Current doctrine offers little direction to courts that must apply the exception. The Supreme Court has not yet identified criteria which reliably identify when states are acting as market participants. Lacking such criteria, courts often look to the "market participant" label itself for guidance. But the label is misleading; it does not adequately describe the dimensions of the exception.

This Comment offers a pragmatic conception of the market participant exception: state exemption from dormant Commerce Clause scrutiny should be limited to those actions available to a private party in the marketplace. Such a limitation denies states the means to regulate in a discriminatory way. Every private party acting in the marketplace faces, at a minimum, two constraints: 1) it cannot regulate ${ }^{12}$ and 2) it is subject to the antitrust laws. ${ }^{13}$ If a state is neither regulating nor taking action that would violate the

than as a market regulator, the dormant Commerce Clause places no limitation on its activities." Id at 93.

- Reeves, Inc. $v$ Stake, 447 US 429, 439 n 12 (1980).

7 Id, quoting Perkins v Lukens Steel Co., 310 US 113, 127 (1940).

${ }^{8}$ Hughes, 426 US at 799-801.

- Reeves, 447 US at 432-33 (sales from a state-owned and operated cement factory).

${ }^{10}$ W.C.M. Window Co., Inc. v Bernardi, 730 F2d 486, 496 (7th Cir 1984).

11 Trojan Technologies, Inc. v Pennsylvania, 916 F2d 903, 912 (3d Cir 1990), cert denied, 111 S Ct 2814 (1991); Big Country Foods, Inc. $v$ Board of Education of Anchorage School District, 952 F2d 1173, 1179 (9th Cir 1992).

12 The term "regulate" is used to convey a state's power to impose rules on the conduct of private parties with whom the state has no contractual relation. 
antitrust laws if carried out by a private party, then the state's action will not violate the dormant Commerce Clause.

Under this "private-party" test, whether a local preference statute is constitutional will depend on the relationship between a state and its subdivisions. A private party may adopt a preference itself but may not impose the preference on other actors either by regulating or by exploiting its market power in violation of the antitrust laws. Under the private-party conception, then, if the state and its subdivisions are independent entities, a state-imposed preference may become an instance of market regulation. ${ }^{14}$ But where, as a matter of state law, a state and its subdivisions must be deemed the same actor, a preference statute should be seen as an example of market participation, exempt from the restrictions of the dormant Commerce Clause.

Section I of this Comment describes the sweep of local preference laws and their unsettled status under the market participant exception. Section II presents and justifies the private-party definition of "market participation." Section III applies the privateparty test to local preference statutes, in the process revisiting the decisions of the Courts of Appeals. This analysis indicates that local preference statutes are not per se unconstitutional.

13 The "private party" used for comparison purposes in this Comment is subject to the antitrust laws even though private parties are, in some instances, immune from antitrust. See, for example, U.S. $v$ Citizens and Southern National Bank, 422 US 86, 111-12 (1975) (discussing banks' exemption from antitrust); Connell Construction Co. $v$ Plumbers \& Steamfitters Local Union No. 100, 421 US 616, 621-23 (1975) (scope of trade union antitrust exemption); Flood v Kuhn, 407 US 258, 284-86 (1972) (baseball held exempt from antitrust). Such exemptions reflect determinations that antitrust scrutiny is inappropriate. But no such determination exists here. Indeed, courts have justified the Commerce Clause immunity of the market participant exception by arguing that antitrust laws will apply to states acting as market participants. See, for example, Wunnicke, 467 US at 98-99, and text accompanying notes $84-87$.

14 See Wyoming, $112 \mathrm{~S} \mathrm{Ct}$ at 802-03 (suggesting that Oklahoma's restrictions on the use of out-of-state coal would not have violated the dormant Commerce Clause if the restrictions had applied only to state-owned facilities and not to private facilities); Charles County $v$ Stevens, 299 Md 203, 472 A2d 12, 19 (1984) (policy allowing only waste generated by county residents to be dumped in county landfill falls within the market participant exception; the policy "does not restrict the disposal of [out-of-state] waste in any other landfill that might be constructed within the County"). 


\section{Local Preference Statutes and the Market Participant EXCEPTION}

\section{A. Local Preference Statutes}

States use a wide variety of mechanisms to further their instate preferences. ${ }^{15}$ A 1992 survey found only six states that applied no formal resident preference. ${ }^{16}$ Most commonly, states use local preferences in "tie-bid" situations: when an in-state and outof-state resident each submit bids at equal cost, the state awards the contract to the resident. ${ }^{17}$ States may also impose a percentage preference: when comparing contract bids, the state discounts the price of in-state bids by a set percentage. ${ }^{18}$ Other states apply reciprocal preferences which handicap out-of-state bidders to the same extent that their own states prefer local bidders. ${ }^{19}$

\section{B. Existing Doctrine: The Market Participant Exception}

The market participant exception reflects the Supreme Court's desire to protect states' autonomy, ${ }^{20}$ even at some cost to the national economy. ${ }^{21}$ At the same time, the Court has taken steps to keep the market participant exception from swallowing the dormant Commerce Clause rule.

${ }^{15}$ See Comment, In-State Preferences in Public Contracting: States' Rights versus Economic Sectionalism, 49 U Colo L Rev 205, 205-208 (1978) (surveying statutes).

${ }_{16}$ The no-preference states are Arizona, California, Colorado, Delaware, Kentucky, and Washington. National Association of State Purchasing Officials, 1992 Survey, Table 43: In State Preference Laws (1992) (on file with U Chi L Rev) ("NASPO Survey"). But note that whether by formal or informal means, all states prefer their residents under at least some circumstances. National Institute of Government Purchasing, Inc., 1991 Survey of In-State (Buy-Local), Buy-American, \& Recycled Product Preferences 1-5 (1992) (on file with U Chi L Rev).

${ }^{17}$ Forty-one states have enacted statutes requiring this practice. NASPO Survey, Table 43 (cited in note 16 ).

18 The NASPO Survey found 10 states which apply a percentage preference to in-state bidders. Id. See, for example, Hawaii Rev Stat \& 103-43 (1985); La Rev Stat Ann $\S \S 38: 2251.1-2,2255$ (West 1989 \& Supp 1993); Mont Code Ann \$§ 18-1-101 through 18-1103 (1987).

19 See, for example, Ga Code Ann § 50-5-60 (Michie 1990); ND Cent Code § 44-08-01 (Supp 1991); Okla Stat § 61-14 (1989). Fourteen states had reciprocal preference statutes in place in 1978. Comment, $49 \mathrm{U}$ Colo $\mathrm{L}$ Rev at 208 (cited in note 15).

${ }^{20}$ Reeves, 447 US at 438 ("Restraint in this area is also counseled by considerations of state sovereignty ....") (citations omitted).

${ }^{21}$ Id at 454 (Powell dissenting) ("The creation of a free national economy was a major goal of the States when they resolved to unite under the Federal Constitution."); H.P. Hood \& Sons, Inc. v Du Mond, 336 US 525, 539 (1949). 
1. An exception for market participants.

The dormant Commerce Clause bars states from advancing "their own commercial interests by curtailing the movement of articles of commerce, either into or out of the state . . .."22 Regardless of a state's ultimate purpose, it may not discriminate "against articles of commerce coming from outside the State unless there is some reason, apart from their origin, to treat them differently."23 State regulations that achieve or aim toward simple economic protectionism face a "virtually per se rule of invalidity."24

Despite this rule against protectionism, the Supreme Court held in Hughes $v$ Alexandria Scrap, Inc. ${ }^{25}$ that "[n]othing in the purposes animating the Commerce Clause prohibits a State ... from participating in the market and exercising the right to favor its own citizens over others." The Hughes Court upheld a Maryland law which made it harder for out-of-state companies to participate in a program offering bounties for the disposal of scrap autos. ${ }^{28}$ Four years later, in Reeves, Inc. $v$ Stake, ${ }^{27}$ the Court found that South Dakota acted as a market participant in giving its residents a priority in sales from a state-owned and operated cement factory. Similarly, the Court in White $v$ Massachusetts Council of Construction Employers, Inc. ${ }^{28}$ upheld the Boston mayor's order that all the city's public works contractors employ at least fifty percent local residents.

22 H.P. Hood \& Sons, 336 US at 535. The Commerce Clause provides that Congress shall have power to regulate commerce among the several states. US Const, Art I, § 8, cl 3. Dormant Commerce Clause restrictions on the states "appear nowhere in the words of the Commerce Clause, but have emerged gradually in the decisions of [the Supreme] Court giving effect to its basic purpose." Philadelphia $v$ New Jersey, 437 US 617, 623 (1978).

2s Philadelphia, 437 US at 626-27. See also New Energy Company of Indiana $v$ Limbach, 486 US 269, 274 (1988) ("state statutes that clearly discriminate against interstate commerce are routinely struck down ... unless the discrimination is demonstrably justified by a valid factor unrelated to economic protectionism") (citations omitted).

For an example of sufficient justification, see Maine v Taylor, 477 US 131, 151-52 (1986) (ban on import of live baitfish due to otherwise unavoidable threat of parasites). For inadequate justifications, see Dean Milk Co. v Madison, 340 US 349, 356 (1951) (municipal ordinance discriminating against out-of-state producers; intended to maintain milk quality), and Baldwin v G.A.F. Seelig, Inc., 294 US 511, 522-23 (1935) (imposition of price floor for out-of-state milk producers intended to maintain "a regular and adequate supply of pure and wholesome milk").

14 Philadelphia, 437 US at 624.

2s 426 US 794, 810 (1976).

16 Id at $800-02,814$.

27447 US 429, 432-33, 440, 446-47 (1980).

28 460 US 204, 205-206, 214-15 (1983). 
In South-Central Timber Development, Inc. $v$ Wunnicke, ${ }^{29}$ however, a plurality of the Court rejected an Alaska requirement that any timber taken from state lands be processed within the state prior to export. According to the Court, Alaska could not use its leverage in the timber market "to exert a regulatory effect in the processing market, in which it is not a participant." wise, the market participant exception would simply swallow the rule that "[s]tates may not impose substantial burdens on interstate commerce even if they act with the permissible state purpose of fostering local industry. ${ }^{{ }_{31}}$

\section{The difficulty of identifying "market participants."}

While the term "market participation" provides a distinctive label for the Commerce Clause immunity set forth in Hughes, the label is unhelpful. The Supreme Court has itself struggled to treat successive cases consistently, appearing to rely as much on its evolving "intuition" as on any concrete standard..$^{32}$ Notably, each author of the Court's market participant opinions dissented in the next. ${ }^{33}$ As a result, courts and commentators continue to search for the precise contours of the market participant exception. ${ }^{34}$

While the Supreme Court ostensibly relies on a distinction between impermissible "regulation" and permissible "participation,"35 this distinction is purely formal and, alone, provides little practical guidance to lower courts. Moreover, the Court has not provided criteria which lower courts could use to distinguish regulation from participation. For example, in New Energy Company

29467 US 82, 84, 99 (1984) (White, joined by Brennan, Blackmun, and Stevens, with Burger and Powell concurring in the judgment).

${ }^{30}$ Id at 98.

31 Id. As Professor Manheim has observed, "[l]est it become too powerful, the allegory of the state as private trader necessarily spawns exceptions, such as the state as monopolist." Karl Manheim, New-Age Federalism and the Market Participant Doctrine, 22 Ariz St L J 559, 608 (1990) (citations omitted).

${ }^{32}$ See Wunnicke, 467 US at 98.

s3 See Reeves, 447 US at 447 (Powell, author of Hughes majority opinion, dissenting); White, 460 US at 215 (Blackmun, author of Reeves, dissenting); Wunnicke, 467 US at 101 (Rehnquist, author of White, dissenting). Observers have pointed to this pattern as evidence of the unsettled nature of the exception. See, for example, Swin Resource Systems, Inc. $v$ Lycoming County, 883 F2d 245, 249 (3d Cir 1989).

34 See Swin Resource Systems, 883 F2d at 251 (describing the distinction between improper regulation and permissible market participation as "problematic"). See also Teresa Gillen, A Proposed Model of the Sovereign/Proprietary Distinction, $133 \mathrm{U}$ Pa L Rev 661, 662 (1985).

ss Wunnicke, 467 US at 93-95. 
of Indiana $v$ Limbach, ${ }^{38}$ the Court did not classify an Ohio tax credit scheme as market participation since taxation is a "primeval" governmental activity. But the Court gave no reason why state spending is any less primeval than state taxation (which is presumably undertaken to support state spending). Frustration with such criteria has led numerous observers to question whether any meaningful differences between states as regulators and as market participants do in fact exist. ${ }^{37}$ Even if state regulation and participation could be distinguished satisfactorily, the distinction is no longer determinative. After Wunnicke, it is not enough for courts to determine whether a state is participating in the market. Courts must also characterize the market in which the state participates, and ascertain whether the state's activities have any "substantial regulatory effect[s]" beyond that market. ${ }^{38}$

It is not clear how a court should go about characterizing the relevant market. For example, the court in Charles County Commissioners $v$ Stevens ${ }^{39}$ observed that a municipality which charged a higher fee for the disposal of out-of-state waste at its dump would be a market participant if the market were characterized as one for waste disposal services, but a regulator if the market were viewed as waste per se. A similar difficulty arose in Smith v Georgia Department of Agriculture. ${ }^{40}$ There, the state granted Georgia farmers a preference in leasing the prime selling areas at a stateowned farmer's market. ${ }^{41}$ The Smith court held that the state had

36 486 US 269, 277 (1988).

${ }^{37}$ See David Pomper, Recycling Philadelphia v. New Jersey: The Dormant Commerce Clause, Postindustrial "Natural" Resources, and the Solid Waste Crisis, $137 \mathrm{U} \mathrm{Pa} \mathrm{L}$ Rev 1309,1322 (1989) ("the line between 'participant' and 'regulator' is notoriously difficult to draw") (citations omitted); Note, The Foreign Commerce Clause and the Market Participant Exception, 25 Vand J Transnational L 257, 288 (1992) ("Apparently, the only remaining valid distinction between Reeves and [Wunnicke] is the foreign commerce issue."); William L. Kovacs and Anthony A. Anderson, States as Market Participants in Solid Waste Disposal Services - Fair Competition or the Destruction of the Private Sector?, 18 Envir L $779,809-10$ (1988) (states are too heavily involved in regulatory activities to act as "participants"). See also Christine Hunter Kellett, The Market Participant Doctrine: No Longer "Good Sense" or "Sound Law", 9 Temple Envir L and Tech J 169, 174 (1990) ("Beyond its conclusions, the Court has given little guidance as to how the determination of participant or regulator is made."); Steven G. Gey, The Political Economy of the Dormant Commerce Clause, 17 NYU Rev L \& Soc Change 1, 64-65 (1989-90) (the Supreme Court has not explained how regulator/participant distinctions can be drawn consistently).

3s Wunnicke, 467 US at 97.

39 299 Md 203, 473 A2d 12, 20 (1983). See also Swin Resource Systems, 883 F2d 245. While the majority found the relevant market to be one "for disposal services," id at 250, Judge Gibbons, dissenting, viewed the market as one for "landfill space." Id at 259.

${ }^{40} 630$ F2d 1081 (5th Cir 1980).

41 Id at 1082. 
regulated the market in "produce sales," 42 but the dissenting opinion argued that Georgia had simply acted in the leasing market. ${ }^{43}$ Until the Supreme Court provides guidance, courts will continue to identify relevant markets differently. ${ }^{44}$

Even if courts can properly characterize the markets in which states participate, courts must then decide whether the states have a "substantial regulatory effect" beyond these markets."5 Once again, the Court has failed to offer a readily accessible basis for making this determination.

Recently, the Court in Building and Construction Trades Council $v$ Associated Builders and Contractors of Massachusetts/ Rhode Island, Inc. ${ }^{48}$ observed that when a private party (the paradigmatic proprietor) participates "in a boycott of a supplier on the basis of a labor policy concern rather than a profit motive," the party in fact seeks to "regulate" the target of the boycott. Therefore, the Court reasoned, a state which employs boycott tactics in order to affect conduct unrelated to a party's "performance of contractual obligations to the State" should be deemed a regulator rather than a market participant. ${ }^{47}$ However, this analysis ill suits the market participant exception.

The Court has held that a state may require that its trading partners hire at least fifty percent local workers, ${ }^{48}$ or refuse to trade with out-of-state parties until all local customers are satisfied. ${ }^{48}$ To the extent that such policies resemble boycotts, they "regulate" the conduct of the state's trading partners in the manner suggested by Building Trades Council. But the Court held these policies to be forms of market participation-not "regulation."

For the Building Trades Council framework to apply, then, a party's performance of her contractual obligations to the state

42 Id at $1083,1085$.

4s Id at 1087 (Randall dissenting).

14 As an example of the Court's inconsistent signals, White held that states may impose conditions beyond "the boundary of formal privity of contract"-so long as actual privity exists. White, 460 US at $211 \mathrm{n} 7$. Yet the Wunnicke plurality suggested that Commerce Clause restraints might arise within the boundary of formal privity and urged that the relevant market be "relatively narrowly defined." 467 US at 97-98.

45 Wunnicke, 467 US at 97.

1993 US LEXIS $1948,{ }^{*} 20$.

17 Id, citing Wisconsin Department of Industry $v$ Gould, 475 US 282, 289 (1985). In Gould, the Court held that Wisconsin's policy of "prohibiting state purchases from repeat labor law violators" constituted regulation, not market participation. 475 US at 289 .

4s White, 460 US at 205-06.

49 Reeves, 447 US at $432-33$. 
must be more closely related to her in-state/out-of-state status than to her compliance with various labor law concerns. It is difficult to see how this could systematically be the case. More likely, federal labor law preemption places a stricter burden on state action than does the dormant Commerce Clause. ${ }^{50}$

The regulatory effects prohibited by the dormant Commerce Clause cannot be identified simply by considering the magnitude of the burden imposed on out-of-state parties by a state's preference statute. For example, the Reeves Court permitted South Dakota to give its own residents a priority in purchasing cement, even though Reeves, Inc., an out-of-state customer, had to reduce its own business by seventy-six percent as a result of the state's action. ${ }^{51}$ That the Court upheld the South Dakota policy despite its dramatic impact strongly suggests that the magnitude of impact does not predict the outcome of market participant cases.

Finally, while economic theory might help identify which state actions have "regulatory" effects, economic analysis does not seem to explain the Supreme Court's market participant holdings. ${ }^{.2}$ Even if it did, courts are generally not equipped to engage in extensive economic analysis. ${ }^{53}$

so It may be questioned whether statutory preemption principles can properly be applied in the dormant Commerce Clause context. See Gould, 475 US at 289 (The market participant exception "reflects the particular concerns underlying the Commerce Clause, not any general notion regarding the necessary extent of state power in areas where Congress has acted.").

s1 447 US at 433 .

s2 See Barbara J. Redman, The Market Regulator-Market Participant Distinction and Supreme Court Vigilance over Discriminatory State Programs: Does Economic Theory Justify the Judicial Effort?, 25 Am Bus L J 585 (1988). As Redman argues, "according to economic theory, there is little merit in maintaining the market regulator-market participant distinction." Id at 586.

ss See American Commercial Lines, Inc. $v$ Louisville \& Nashville RR Co., 392 US 571, $586 \mathrm{n} 16$ (1968) (the Court is not particularly suited to consider economic arguments). Since economic analysis includes its own set of assumptions regarding economic efficiency, use of this approach-even if practically feasible-risks that courts would wrongfully displace legislative judgments not properly reviewed by courts. Courts have traditionally abstained from enforcing any particular economic theory. See Ferguson v Skrupa, 372 US 726, 730 (1963).

Furthermore, market participant cases often present facts which are "subtle, complex, politically charged, and difficult to assess under traditional Commerce Clause analysis. ... [T] he adjustment of interests in this context is a task better suited for Congress . . .." Reeves, 447 US at 439. Preference statutes require states to strike a precise balance between competing interests. States must conserve tax dollars and at the same time satisfy constituents' desires for state contracts. Graduated percentage-preference statutes demonstrate the degree to which states fine-tune these calculations: Alaska's preferences vary between 3, 5, and 7\%; Hawaii's between 3,5, and 10\%. NASPO Survey, Table 43 (cited in note 16). 


\section{Bypassing the difficulty.}

The difficulties inherent in the market participant/market regulator distinction have frustrated many observers, who have sought alternatives to the Court's ambiguous doctrine. Some commentators argue that dormant Commerce Clause cases can be resolved by scrutinizing states' motives. ${ }^{54}$ The Supreme Court, however, has expressly ignored considerations of state motive in its market participation analysis. ${ }^{55}$ Some litigants have tried to avoid the Commerce Clause issue by challenging resident preference policies on other constitutional grounds, including the Privileges and Immunities or Equal Protection Clauses. Such challenges have met with mixed success..$^{56}$

Many observers have simply called for the abolition of the market participant exception altogether. ${ }^{67}$ Frequently, these argu-

54 See Donald H. Regan, The Supreme Court and State Protectionism: Making Sense of the Dormant Commerce Clause, 84 Mich L Rev 1091, 1206-07 (1986) (arguing that the Court has, in fact, done no more than screen state actions for "protectionist purpose"); Note, The Market Participant Test in Dormant Commerce Clause Analysis-Protecting Protectionism?, 1985 Duke L J 697, 732-33 (arguing that state actions motivated by economic protectionism should not be deemed "market participation"). But see Steven BrekerCooper, The Commerce Clause: The Case for Judicial Non-Intervention, 69 Or L Rev 895, 909 (1990) (arguing that Regan's thesis involves the "somewhat preposterous claim that the Justices are not aware of their own decision-making processes").

${ }^{55}$ The Supreme Court was indifferent to concerns that South Dakota had reduced its out-of-state cement sales "in response to political concerns that would likely be inconsequential to a private cement producer ...." Reeves, 447 US at 453 (Powell dissenting). Similarly, Justice Blackmun's argument that the preference at issue in White was simply "parochial favoritism" did not sway the Court. 460 US at 223 (Blackmun dissenting).

se See, for example, Salla $v$ County of Monroe, 48 NY2d 514, 399 NE2d 909 (1979) (challenge to New York preference statute on Privileges and Immunities, Commerce Clause, and Equal Protection grounds). Privileges and Immunities challenges under US Const, Art IV, $\S 2$ have been the most successful of late. See United Building \& Construction Trades Council v Camden, 465 US 208, 221 (1984) (striking, on Privileges and Immunities grounds, a preference provision similar to that upheld under the market participant exception in White).

Courts do not agree, however, on the applicability of the Privileges and Immunities Clause to local preference statutes. Compare Wyoming $v$ Antonich, 694 P2d 60, 64 (Wyo 1985) (Wyoming Preference Act does not violate the Privileges and Immunities Clause) with Salla, 399 NE2d at 910 (New York preference statute violates Privileges and Immunities Clause); People ex rel Bernardi v Leary Const. Co., Inc., $102 \mathrm{IIl}$ 2d 295, 464 NE2d 1019, 1022-23 (1984) (Privileges and Immunities violation by Illinois Preference Act). See generally Note, Hiring Preference Acts: Has the Supreme Court Rendered Them Violations of the Privileges and Immunities Clause? 54 Fordham L Rev 271 (1985).

${ }^{87} \mathrm{See}$, for example, Wunnicke, 467 US at 101 (Brennan concurring) (pointing to the "inherent weakness of the doctrine"); Swin Resource Systems, 883 F2d at 261 (Gibbons dissenting) ("The notion that state enterprises 'participate' in the market on the same footing as private concerns is a chimera.").

See also Breker-Cooper, 69 Or L Rev at 935 (cited in note 54) (the Court should no longer take up Commerce Clause cases); Manheim, 22 Ariz St L J at 606, 622-23 (cited in 
ments rely on Garcia $v$ San Antonio Metropolitan Transportation Authority, ${ }^{58}$ which dispensed with the governmental/proprietary distinction in the context of state immunity from federal regulation. ${ }^{59}$ However, the Court recently affirmed the use of a regulator/ proprietor distinction in analyzing the preemption of state laws by federal regulation..$^{60}$ And in three cases since Garcia, the Supreme Court has recognized the continuing validity of the market participant exception to the dormant Commerce Clause. ${ }^{61}$

As a result, courts must continue to apply a market participant exception, even if unsure of its actual nature. Case law on local preference statutes reflects this uncertainty and suggests the need for a clearer approach to the exception.

C. Local Preference Statutes as Market Participation: W.C.M., Trojan, and Big Country

Three courts of appeals have considered whether local preference statutes constitute market participation. In W.C.M. Window Co., Inc. $v$ Bernardi ${ }^{62}$ the Seventh Circuit refused to apply the

note 31) (arguing that the market participant distinction is unworkable; instead, Congress should intervene when it finds that a state law "truly jeopardizes the national interest in free trade"); Richard S. Myers, The Burger Court and the Commerce Clause: An Evaluation of the Role of State Sovereignty, 60 Notre Dame L Rev 1056, 1057 (1985) (arguing that the Burger Court failed to revive state sovereignty in the Commerce Clause area); Jonathan D. Varat, State, Citizenship, and Interstate Equality, 48 U Chi L Rev 487, 492-93 (1981) (suggesting that the Court has not coped with the complexity of the task of defining the proper scope of states' authority to favor their residents).

ss 469 US 528 (1985). See, for example, Kellett, 9 Temple Envir L \& Tech J 169 (cited in note 37 ).

so By a 5-4 margin, Garcia held that the Fair Labor Standards Act applied to the San Antonio transit authority and overruled National League of Cities $v$ Usery, 426 US 833 (1976), which had reached an opposite conclusion on the grounds that the federal government could not regulate states" "traditional governmental functions." Garcia, 469 US at 545-47.

- See Building and Construction Trades Council v Associated Builders and Contractors of Massachusetts/Rhode Island, Inc., 1993 US LEXIS 1948, *17 (opinion for the unanimous Court notes the line of preemption decisions which "support the distinction between government as regulator and government as proprietor").

i1 Wyoming v Oklahoma, 112 S Ct 789, 802-03 (1992), citing Reeves, 447 US 429 and Hughes, 426 US 794 ("We have recognized that the Commerce Clause does not restrict the State's action as a free market participant."); New Energy Co. of Indiana v Limbach, 486 US 269, 277 (1988), citing Hughes; Wisconsin Department of Industry v Gould, 475 US 282, 289 (1986), citing Hughes and White, 460 US 204.

83 730 F2d 486, 496 (7th Cir 1984) (treating Ill Rev Stat ch 49, §§ 269-274 (1981)). After Bernardi, the Ilinois legislature passed a successor statute to the Illinois Preference Act. The new statute, Ill Rev Stat ch 48, $\$ 2201-07$ (1986 \& Supp 1992), was challenged in turn. See E \& E Construction Co. v Illinois, 674 F Supp 269 (N D Ill 1987). However, no final resolution of this case is reported. 
market participant exception to an Illinois preference law requiring that all public works contracts employ only Illinois workers. The state had exceeded its authority, Judge Posner held, since the "preference law applies to every public construction contract in Illinois ..." whether or not state-funded or administered. ${ }^{63}$ Especially where local school boards enjoy substantial autonomy in running their affairs, "[ $t]$ he difference between the state's preferring state residents in its own dealings and forcing local agencies to do so in theirs is both analytical and quantitative."

By contrast, the Third Circuit held in Trojan Technologies, Inc. $v$ Pennsylvania ${ }^{65}$ that Pennsylvania acted as a market participant when it required that all its political subdivisions purchase products containing only U.S.-made steel. The court found that Pennsylvania's local government units "exist only through affirmative acts of the state." attendant on making such affirmative grants of power, the Commonwealth may not also restrict the contracting authority of such local bodies." discretion of its political subdivisions, the state and its subdivisions could be considered a single purchaser.

Similarly, the Ninth Circuit in Big Country Foods, Inc. $v$ Board of Education of Anchorage ${ }^{68}$ upheld an Alaska statute requiring that state-funded schools give a seven percent bid preference to in-state milk suppliers. The court found that Alaska was "simply making a decision as to what it will pay for a product bought on the open market."69 Through the preference statute, Alaska and its subdivisions became the same "market participant."

To avoid arguments "over the extent of Alaska state control of the local school districts," the Big Country court preemptively held that political subdivisions are not separate from state control. ${ }^{70}$ The court noted that a "rule that would consider some political subdivisions as separate from state controls would lead to diffi-

63 W.C.M., $730 \mathrm{~F} 2 \mathrm{~d}$ at 495.

Id at 496 .

os 916 F2d 903, 911 ( $3 \mathrm{~d}$ Cir 1990). The preference at issue in Trojan applied to a "broadly defined" list of public agencies, set forth in $73 \mathrm{~Pa}$ Cons Stat Ann $\S 1886$. Id at 905.

s8 Id at 911.

id.

os 952 F2d 1173, 1179 (9th Cir 1992) (treating Alaska Stat $\S 36.15 .050$ ).

${ }^{60} \mathrm{Id}$ at 1181 .

${ }^{70}$ Id at 1179. 
cult case-specific inquiries into the degree of subdivision autonomy." 1

In fact, such case-specific inquiries are necessary. Otherwise, courts run a significant risk of misapplying the market participant exception. States' preference policies can be expected to vary from state-to-state; this, in itself, does not raise dormant Commerce Clause concerns. ${ }^{72}$ And as W.C.M., Trojan, and Big Country illustrate, the degree of autonomy of a state's subdivisions affects the extent to which a state may extend the scope of its preference policies. Therefore, the particular features of individual states' local government law can be expected to affect the constitutionality of individual local preference statutes. The market participant exception should therefore be restated in a manner that ensures that courts treating local preference statutes will properly account for such local variation.

\section{The Market Participant Exception Restated}

\section{A. The Private-Party Test}

This Comment argues that "market participation" should be defined as those state actions which could legally be undertaken by a private party acting in the market. This definition offers courts a framework more workable than the Supreme Court's regulator/participant distinction. Using a private-party test for states' Commerce Clause immunity may better prevent states from imposing conditions "that have a substantial regulatory effect outside of that particular market."'3

Rather than requiring a state to mimic a private party, the private-party test asks whether a private party could mimic the state. Under this test, states can choose their trading partners in a manner as biased-but no more biased-than could private parties. $^{74}$

"1 Id (emphasis in original). The court also noted that "[a] rule that would consider all political subdivisions as separate from state control for market participant purposes would be anomalous to the proposition that political subdivisions exist at the will of the state." Id.

72 See Varat, 48 U Chi L Rev at 522 (cited in note 57):

[The Framers] sanctioned a diversity of policies among the states. That diversity inevitably distorts business location and resource allocation decisions from what they would be in a true free-trade area. The Framers thus compromised to some degree the national free-trade objectives of the commerce clause in the interest of state power.

7s Wunnicke, 467 US at 97.

34 Note that other doctrines may still govern state action regardless of the outcome of market participant analysis. See, for example, US v Hagen, 782 F Supp 1351, 1359 (D Neb 
Although previous commentators have focused on the participant/private party analogy, they have generally underplayed or ignored the restraints on private parties. For example, while Kovacs and Anderson argue that a state acting. as a market participant should enjoy "all the freedoms of a private-sector entrepreneur," they argue that this principle should be limited by considerations of "fairness"-hardly a predictable criterion. ${ }^{75}$

A 1985 Duke Law Journal note presents a slightly different analysis. ${ }^{26}$ The note advocates a private-party measure of market participation, with several modifications. It argues that the market participant exception should encompass only those cases where the state acts "in the form, and with the intent and impact, of an economically rational private market force." ${ }^{\prime 7}$ Further, the state should also be required to show that its preference has "a sound economic basis, considering the state as a private entity, without regard to the potential or actual economic benefits to its citizens." The state preference should create an economic benefit likely to exceed the benefits obtainable from pursuing nondiscriminatory alternatives. ${ }^{79}$

However, the "sound economic basis" requirement and the monitoring of states' intentions advocated in the Duke Law Journal note are more prescriptive than workable under current conditions. Courts can rarely, if ever, second-guess a legislative determination that a particular course of action had a "sound economic basis." 80 And where the Court confers market participant status, even an overtly protectionist motive becomes irrelevant. ${ }^{\mathbf{1}}$

1991) ("a regulation or statute may be sustained against a Commerce Clause challenge, but that same regulation may still be held to violate the Privileges \& Immunities Clause").

${ }_{75}$ Kovacs \& Anderson, 18 Envir L at 803 (cited in note 37). Professor Coenen similarly underplays the relevance of the private-party analogy by burying it within his proposed four-prong test for the market participant exception. Dan T. Coenen, Untangling the Market Participant Exemption to the Dormant Commerce Clause, 88 Mich L Rev 395, 421-26, 430-35, 441 (1989).

78 Note, 1985 Duke L J 697 (cited in note 54).

$77 \mathrm{Id}$ at 733 .

${ }^{78} \mathrm{Id}$.

79 Id.

so See text accompanying notes 52-53.

81 See text accompanying notes 54-55. See generally Gey, 17 NYU Rev L and Soc Change at 64-65 (cited in note 37 ). 
B. "Participation" and the Antitrust Laws

The private-party test looks to the antitrust laws ${ }^{82}$ to ensure that states do not abuse their market powers in the guise of "market participants." It does not, however, substitute antitrust liability for dormant Commerce Clause scrutiny. Instead, the privateparty test refers to antitrust law to help determine when dormant Commerce Clause scrutiny would be appropriate. Under the private-party test, if a state takes actions that would violate the antitrust laws if undertaken by a private party, the state would be subject to dormant Commerce Clause scrutiny. Thus, states would be prevented from using monopoly power or vertical restraints of trade to achieve the sort of "substantial regulatory effect" forbidden by Wunnicke. ${ }^{83}$

A number of courts and commentators have already used antitrust principles to limit the market participant exception. ${ }^{84}$ For example, Justice White relied on an antitrust analogy in holding that the preference at issue in Wunnicke had an overly "regulatory effect." ${ }^{\text {"8s }}$ Likewise, in Western Oil and Gas Association v Cory, ${ }^{88}$ the Ninth Circuit declined to apply the market participant exception since California's Lands Commission had "a complete monopoly over the sites" being leased..$^{87}$

e2 Federal antitrust legislation includes the Sherman Antitrust Act, 15 USC § 1 et seq (1988), the Clayton Act, 15 USC $\S 12$ et seq (1988), and the Federal Trade Commission Act, 15 USC \& 41 et seq (1988).

ss 467 US at 97.

st For example, Kovacs and Anderson propose that the market participant exception should be bounded by considerations of "fairness or evenhandedness." Kovacs and Anderson, 18 Envir L at 808 (cited in note 37). To the extent that states can claim antitrust immunity while acting as market participants, the "fairness" principle would then invoke the restrictions of the dormant Commerce Clause. Id. Otherwise, the authors warn, "the state as a market participant can provide any service in a manner that eliminates competition ...." Id. See also Note, The Delaware Takeover Statute: Constitutionally Infirm Even Under the Market Participant Exception, 17 Hofstra L Rev 203 (1988). This note argues that because Delaware occupies a monopoly position in the market for corporate charters, the Delaware takeover statute should not be treated as a form of market participation. Id at 227-34.

ss 467 US at 98-99 ("It is no defense in an action charging vertical trade restraints that the same end could be achieved through vertical integration .....").

s6 726 F2d 1340 (9th Cir 1984), aff'd mem, 471 US 81 (1985).

${ }^{87}$ As the court noted, "[ $[t]$ he permanency of plaintiff's facilities does not permit them to 'shop around.' There is no other competitor to which they can go for the rental of the required strip of California coastline." Id at 1343. But compare LeFrancois $v$ Rhode Island, 669 F Supp 1204, 1212 (D RI 1987) (discussing but rejecting a "monopoly exception" to the market participant doctrine). 
Notably, the doctrine of state action antitrust immunity set forth in Parker $v$ Brown $^{88}$ does not affect the private-party test's use of antitrust principles to define the scope of the market participant exception. The Court has suggested that Parker immunity does not apply to states acting as market participants. ${ }^{89}$ Also, bear in mind that the Commerce Clause doctrine and the antitrust doctrine are independent of one another. Parker immunity reflects the congressional intent underlying the Sherman Act..$^{90}$ In contrast, the dormant Commerce Clause doctrine reflects the Court's understanding of the economic policies underlying the Commerce Clause. ${ }^{91}$ Immunity in the antitrust context does not warrant immunity in the Commerce Clause context.

The private-party test prevents states from taking advantage of their Parker immunity to achieve economic protectionism. ${ }^{82}$ Since private parties cannot create Parker immunity, any state action which evades antitrust review under Parker immunity is simply not defined as "market participation." As a result, such state

ss 317 US 341, 350-51 (1943).

89 See Columbia v Omni Outdoor Advertising, Inc., 111 S Ct 1344, 1351 (1991) (Parker immunity "does not necessarily obtain where the State acts not in a regulatory capacity but as a participant in a given market."); Jefferson County Pharmaceutical Ass'n, Inc. v Abbott Laboratories, 460 US 150, 154 (1983) (state action immunity "does not apply where a State has chosen to compete in the private retail market").

The uncertain scope of state antitrust immunity already prompts state purchasing officials to guard against antitrust violations. See National Association of Attorneys General \& National Association of State Purchasing Officials, Government Purchasing and the Antitrust Laws at 35-38 (Committee on the Office of Attorney General of the National Association of Attorneys General, 1977) (discussing potential liability for price-fixing, refusal to deal, exclusive requirement contracting, and bribery). See generally Ann Berkley Rodgers, The Limits of State Activity in the Interstate Water Market, 21 Land \& Water L Rev 357, 379 (1986); L. David Condon, The Never-Ending Story: Low-Level Waste and the Exclusionary Authority of Noncompacting States, 30 Nat Res J 65, 83 (1990).

so Parker, 317 US at 351-52. The Local Government Antitrust Act of 1984, 15 USC $\S \S$ 34-36 (1988), which immunizes local government entities and officers from damages liability under the Clayton Act, can be treated in the same manner as Parker immunity. The Act reflects congressional concern that antitrust damages would "undermine a local government's ability to govern in the public interest." Local Government Antitrust Act, HR Rep No 98-965, 98th Cong, 2d Sess 2 (1984), reprinted in 98 USCCAN 4602, 4603 (1984). However, the Act does not bar suits for injunctive relief. Paragould Cablevision, Inc. $v$ City of Paragould, 739 F Supp 1314, 1317 (E D Ark 1990). Whatever the scope of the local government immunity created by the Act, the immunity does not apply to private parties and therefore should not be considered when applying the private-party test of market participation.

${ }^{21}$ H.P. Hood \& Sons $v$ Du Mond, 336 US 525, 539 (1949) ("Such was the vision of the Founders; such has been the doctrine of this Court which has given it reality.").

${ }^{92}$ See Philadelphia v New Jersey, 437 US 617, 624 (1978) (simple economic protectionism subject to "virtually per se rule of invalidity"). 
action could have no immunity from dormant Commerce Clause challenges.

\section{The Private-Party Test of "Market Participation" Applied}

This Section illustrates how the private-party test could enhance market participant exception analysis, by applying the test to past Supreme Court cases. Like a private party, a state may choose to buy scrap from whom it likes (Hughes), sell cement to whom it likes (Reeves), or hire the contractors whom it likes (White). But, again like a private party, a state may not tell other parties to have their lumber processed by a particular processor (Wunnicke).

In Reeves, the Court affirmed South Dakota's policy of giving residents a priority in sales from the state's cement factory. The Court itself noted "the long recognized right of a trader or manufacturer, engaged in an entirely private business, freely to exercise his own independent discretion as to parties with whom he will deal." ${ }^{3}$ Unsurprisingly, Reeves then recognized that "the Commerce Clause places no limitations on a State's refusal to deal with particular parties when it is participating in the interstate market in goods." ${ }^{24}$ Nor did any abuses of market power present themselves. No entry barriers kept private parties from beginning to manufacture their own cement; the Court rejected the argument that South Dakota had supplanted the free market for cement as both "simplistic and speculative."

In contrast, the preference at issue in Wunnicke, if pursued by a private party, could well be characterized as a "classic example of the tying arrangement." purchasers to have their lumber resawed in-state even though, absent the tie, "absolutely no market for domestic resawing" existed. ${ }^{97}$ Thus, the Wunnicke preference does not qualify as "mar-

's Reeves, Inc. $v$ State, 447 US 429, 438-39 (1980), quoting US $v$ Colgate \& Co., 250 US 300,307 (1919).

24 South-Central Timber Development, Inc. v Wunnicke, 467 US 82, 94 (1984) (summarizing Reeves).

${ }^{95}$ Reeves, 447 US at 445.

36 467 US at 102 (Rehnquist dissenting), citing United States Steel Corp. v Fortner Enterprises, Inc., 429 US 610, 619-21 (1977).

97 Wunnicke, 467 US at 86 n 5, citing Joint Appendix at 121a-22a. For the application of tying theory to market participants, see also Charles $\mathrm{H}$. Clarke, Local Hire and the State-Market-Participant Doctrine: A Trojan Horse for the Commerce Clause Power of Congress, 33 Cleve St L Rev 191, 214-15 (1984-85). In general, "the vice of tying arrangements lies in the use of economic power in one market to restrict competition on the merits in another, regardless of the source from which the power is derived and whether the power 
ket participation." And, falling back on traditional dormant Commerce Clause analysis, the Court then rejected the preference as an instance of overt protectionism. ${ }^{98}$

\section{Local Preference Statu'tes as "Private-Party" Action}

Under the private-party test, local preference statutes will not automatically violate the dormant Commerce Clause. A local preference statute will satisfy the Commerce Clause under two conditions: 1) the preference must be a choice of trading partners that a private party could make, and 2) the choice must only govern the state's own transactions. Since local preference statutes impose a preference on a state's political subdivisions, whether a state can satisfy the second condition will depend upon the degree of autonomy its subdivisions enjoy-a matter of state law.

\section{A. A State May Prefer Its Residents}

Generally, a local preference is a choice available to private parties. A private contractor can choose to "hire local" if it so desires. Similarly, a private consumer could buy local or "buy American"-decisions that are commonly made. Consumers may even organize boycotts if they so desire.99

Against this backdrop, the courts in W.C.M., Trojan, and Big Country lost little time concluding that the preferences they faced were generically valid. The Trojan court declared itself "satisfied that if Pennsylvania is only a participant, the [Commerce Clause] inquiry is at an end." ${ }^{100}$ Likewise, the W.C.M. court noted that if Illinois "had limited the preference law to construction projects financed (in whole or in part) or administered by the state, it would

takes the form of a monopoly or not." Northern Pacific Railway Co. $v$ United States, 356 US 1, 11 (1958). See also Continental T.V., Inc. $v$ GTE Sylvania Inc., 433 US 36, 65-66 (1977) (White concurring). For discussion and criticism of this line of cases, see generally Dominick T. Armentano, Antitrust and Monopoly: Anatomy of a Policy Failure 198-225 (John Wiley \& Sons, 1982); Frank H. Easterbrook, The Limits of Antitrust, 63 Tex L Rev 1, 4-14 (1984) (collecting authors).

98 Wunnicke, 467 US at 99 ("Viewed as a naked restraint on export of unprocessed logs, there is little question that the processing requirement cannot survive scrutiny under the precedents of the Court.").

'9 See, for example, Building and Construction Trades Council $v$ Associated Builders and Contractors of Massachusetts/Rhode Island, Inc., 1993 US LEXIS 1948, *20-21; Gould, 475 US at 290.

100 Trojan Technologies, Inc. v Pennsylvania, 916 F2d 903, 910 (3d Cir 1990), citing White, 460 US at 210. See also Big Country Foods, Inc. $v$ Board of Education of Anchorage School District, 952 F2d 1173, 1177 (9th Cir 1992). 
be clear after White that the law did not violate the commerce clause."101

B. Specific Local Preference Statutes May Be Disguised Instances of Improper Market Regulation

Even if a "preference" is valid, the dormant Commerce Clause may bar the state from imposing the preference on its subdivisions. ${ }^{102}$ The limitations that apply to private parties-the antitrust laws and the inability to engage in traditional regulation-suggest the following principle: private parties may not impose their market preferences on others. The private-party test applies this principle to local preference statutes, suggesting that such statutes will violate the Commerce Clause unless the state and its subdivisions are the same "participant." Whether this is so will depend upon the legal relationship between a state and its subdivisions, a relationship which varies from state to state.

\section{Legal relationship of state and subdivision.}

Since the status of political subdivisions is a matter of state law, ${ }^{103}$ subdivisions' autonomy may be expected to vary significantly. Unless courts make state-specific inquiries in local preference statute cases, they must settle for the imprecision of generalized doctrines of local government. ${ }^{104}$ According to such doctrines,

${ }_{101}$ W.C.M. Window Co., Inc. v Bernardi, 730 F2d 486, 495 (7th Cir 1984).

${ }^{102}$ States "may not avoid the strictures of the Commerce Clause by curtailing the movement of articles of commerce through subdivisions of the State, rather than through the State itself." Fort Gratiot Sanitary Landfill, Inc. v Michigan Department of Natural Resources, 112 S Ct 2019, 2024 (1992).

${ }^{103}$ Avery v Midland County, 390 US 474, 480 (1968) ("the forms and functions of local government and the relationships among the various units are matters of state concern"). See also South Florida Chapter of Associated General Contractors of America, Inc. v Dade County, 723 F2d 846, 852 (11th Cir 1984) (extent of political subdivision's power to depart from competitive bidding practices is a matter of state law).

106 Commentators continue to cite the supremacy of state government over its subdivisions, a theme developed in such cases as Hunter v Pittsburgh, 207 US 161, 178-79 (1907). See, for example, Gerald Frug, The City as a Legal Concept, 93 Harv L Rev 1059, 1062-67, 1105-20 (1980) (arguing that conscious choices in the political process have rendered cities powerless to solve their own problems). But Professor Williams argues that Professor Frug has projected his own ideology into the inquiry of the scope of local governmental authority, arriving at biased conclusions. Joan C. Williams, The Constitutional Vulnerability of American Local Government: The Politics of City Status on American Law, 1986 Wis L Rev 83, 150-53. 
political subdivisions are creations of state government whose powers can be modified or withdrawn at the state's discretion. ${ }^{105}$

Many states, however, have abrogated the constitutional structure which underlies this doctrine. ${ }^{106}$ And the sheer number and variety of local government entities-over 80,000 in $1990^{107}$ - strongly suggest that even within a single state, a simple rule of thumb will not cover all local preference contingencies. Thus, the blanket assertions characterizing the relationships between the states and subdivisions in W.C.M., Trojan and Big Country were inappropriate. ${ }^{108}$ Their cursory treatment of these state law issues is surprising. Federal courts frequently account for variations in state local government law in analogous situations, such as Parker antitrust immunity, Eleventh Amendment immunity and diversity jurisdiction.

a) Antitrust immunity of local governments. Parker immunity extends to a state's political subdivisions only when they act pursuant to a state policy of displacing competition. ${ }^{109}$ The greater the political subdivision's autonomy, the more specific the state's authorization of anticompetitive activity must be in order for Parker immunity to apply to the subdivision. ${ }^{110}$ This inquiry

${ }^{105}$ For example, the Hunter Court affirmed the power of the state to revoke city authority. 207 US at 178-79. See also Atkin $v$ Kansas, 191 US 207, 220-21 (1903) (noting the power of a state to repeal the charter and destroy the municipal corporation); Wisconsin Public Intervenor v Mortier, 111 S Ct 2476, 2483 (1991).

${ }^{108}$ See Chester J. Antieau, 1 Municipal Corporation Law $\S 3.00$ et seq (Matthew Bender, 1989) (summarizing the states' efforts to empower their political subdivisions). For example, see Iowa Const, Art 3, § 38A:

Municipal corporations are granted home rule power and authority, not inconsistent with the laws of the General Assembly, to determine their local affairs and government -...

The rule or proposition of law that a municipal corporation possesses and can exercise only those powers granted in express words is not a part of the law of this state. Note that at the same time that Iowa abrogated Dillon's rule, it left open the possibility that state laws will automatically preempt local ordinances "inconsistent with the laws of the general assembly ...." Id.

${ }_{107}$ Richard Briffault, Our Localism: Part II-Localism and Legal Theory, 90 Colum L Rev 346, 348-56 (1990) (noting the disparities between, for example, cities and suburbs).

${ }^{203}$ See W.C.M., 730 F2d at 495 ("for many purposes . . . every local government unit in Illinois is a part of the state government; but maybe not for the purpose of evaluating Illinois' preference law under the commerce clause"); Big Country, 952 F2d at 1179 ("Political subdivisions generally exist at the will of the state.").

${ }^{108}$ Hallie v Eau Claire, 471 US 34, 39-40 (1985) (summarizing cases).

110 See, for example, Community Communications Co., Inc. $v$ Boulder, 455 US 40, 52 56 (1982) (home rule grant of power to municipality to govern its local affairs does not constitute authorization for municipality to restrain competition in the cable industry). This principle has been criticized. See Note, Municipal Antitrust Immunity After City of 
turns on a construction of state law. A local entity acts as an agent of the state when the state's grant of authority to act indicates "that the legislature contemplated the kind of action complained of."111 Subdivisions "must do more than merely produce an authorization to 'do business' to show that the state's policy is to displace competition."112

Of course, Parker immunity is not perfectly analogous to the market participant exception. ${ }^{113}$ A subdivision can obtain Parker immunity while remaining an independent entity; ${ }^{114}$ the state's authorization of an anticompetitive policy does no more than offer the subdivision an option without requiring the subdivision to pursue the policy. ${ }^{110}$ In contrast, a state cannot constitutionally subject an independent subdivision to a local preference statute.

b) Other references to state law of local government. The need to look to state law of local government also has parallels in the Eleventh Amendment context. For example, Mt. Healthy

Columbia v. Omni Outdoor Advertising, Inc., 111 S Ct 1344 (1991), 67 Wash L Rev 479 (1992). This note argues that the Supreme Court's application of the Parker doctrine to home rule entities takes inadequate account of the fact that "most states have a fairly welldeveloped common law circumscribing home rule powers." Id at 500. If this were taken into account, the note concludes, courts could better assess whether a facially broad grant of home rule authority foreseeably contemplated the anticompetitive activity at issue. Id.

11 Lafayette v Louisiana Power \& Light Co., 435 US 389, 394 (1978), quoting Lafayette v Louisiana Power \& Light Co., 532 F2d 431, 434 (5th Cir 1976).

112 Lancaster Community Hospital v Antelope Valley Hosp. Dist., 940 F2d 397, 403 (9th Cir 1991), cert denied, 112 S Ct 1168 (1992). The Lancaster court withheld antitrust immunity from a hospital district since its state authorization did not extend to anticompetitive activities: "instead of making regulation the order of the day in the hospital service sector of the economy, [the state had] committed itself to a competitive market." Id.

For sufficient legislative authorization, see, for example, $C \& A$ Carbone, Inc. $v$ Clarkstown, 770 F Supp 848 (S D NY 1991) (treating NY Town Law $\$ \S 130,198(9), 221$ (McKinney $1987 \&$ Supp 1993)). The $C \& A$ court found that the "anti-competitive" provisions of the local law were "the foreseeable result" of "several New York statutes which authorize local control over the disposal and dumping of local garbage." Id at 851-52.

113 Note that the political-subdivision aspect of Parker immunity is discussed only as an illustration of federal courts' use of state law of local government. This is not intended to suggest that the view of local government entities under the Parker doctrine should control in market participant cases. As discussed in text at notes 88-91, the policies underlying Parker immunity are wholly distinct from those underlying the dormant Commerce Clause.

${ }^{116}$ Fuchs v Rural Electric Convenience Cooperative, Inc., 858 F2d 1210, 1214 (7th Cir 1988), citing Hallie v Eau Claire, 471 US 34, 42 (1985) ("The state policy need not compel the municipality to take the challenged action; it is enough that anticompetitive effects are reasonably foreseeable consequences of the state's grant of authority.").

116 Indeed, the scope of local entities' Parker immunity is even broader "than what is applied to determine the legality of the municipality's action under state law." City of Columbia v Omni Outdoor Advertising, Inc., 111 S Ct 1344, 1350 (1991). 
Board of Education $v$ Doyle ${ }^{116}$ presented the issue whether a local board of education would be treated as an arm of the State, protected by the State's Eleventh Amendment immunity, or as an independent political subdivision to which the Eleventh Amendment does not extend. The Court based its holding, in part, "upon the nature of the entity created by state law."117 Because Ohio law excluded school districts from the "State," no sovereign immunity attached. ${ }^{118}$

The Supreme Court has required the same inquiry for determining diversity jurisdiction. In Moor $v$ Alameda County, ${ }^{119}$ the Court considered whether diversity jurisdiction lay in an action brought by an Illinois citizen against a California county for injuries suffered when a deputy sheriff wrongfully fired his shotgun. The Court held that "a political subdivision of a State, unless it is simply 'the arm or alter ego of the State,' is a citizen of the State for diversity purposes." 120 To determine whether the county could properly be considered "an arm of the state," the Moor Court conducted a "detailed examination" of California law and found "persuasive indicia of the independent status occupied by California counties relative to the State of California."121

\section{Dillon's rule, home rule, and local autonomy.}

The relationships between states and their political subdivisions fall along a range between dependence and independence. At one end of the range, some state laws view political subdivisions as no more than creations of state government. As such, the subdivisions' powers can be modified or withdrawn at the state's discretion. ${ }^{122}$ This principle is known as "Dillon's rule."123 However, states often depart from Dillon's rule by providing their subdivisions with autonomy over local affairs. Although the degree of au-

118429 US 274 (1977).

${ }^{112}$ Id at 280.

118 Id at $280-81$.

110411 US 693 (1973).

120 Id at 717, quoting State Highway Comm'n of Wyoming v Utah Construction Co., 278 US 194, 199 (1929).

${ }^{121}$ Id at 719-20 (citing the array of powers granted to the county: to sue and be sued, levy taxes, sell or hold property, provide a variety of public services, and issue bonds). Alameda County argued unsuccessfully that diversity did not exist because Alameda was an agent of the state, which is not deemed a person for diversity purpases. Id at 696-97.

${ }^{122}$ See text accompanying note 105.

${ }^{123}$ Dillon's rule takes its name from the 19th century works of John F. Dillon, in particular his Treatise on the Law of Municipal Corporations (Cockcroft, 1872). See Williams, 1986 Wis L Rev at 88-100 (cited in note 104). 
tonomy provided varies widely from state to state, the grant of this autonomy is generally labelled home rule.

Where Dillon's rule governs a state's relations with its subdivisions, the private-party test would suggest that a local preference statute does not violate the Commerce Clause. When political subdivisions are deemed mere creatures of the state, purchases made by political subdivisions become, effectively, the purchases of the state-not the purchases of autonomous entities. As the Trojan court noted, in such cases the suppliers for a local public entity could be thought of as "supplying for the state."124

Home rule provisions mitigate the effects of Dillon's rule by empowering subdivisions to manage their own local affairs, free of interference from the state legislature. ${ }^{125}$ Home rule serves two purposes: it is a source of local authority, and it may limit the power of the state legislature over its subdivisions. ${ }^{126}$ By 1989 , thirty-seven states had adopted some form of home rule, ${ }^{127}$ and these provisions bring specific state/subdivision relationships into sharp focus. The variance among states' home rule regimes defeats any generalizations regarding local preference statutes. In addition, the presence of a home rule provision will not, by itself, guarantee local autonomy; such provisions can be nullified through actual usage. ${ }^{128}$ To assess whether a matter is of statewide interest or falls within the scope of local affairs requires a fact-specific, state-bystate analysis. ${ }^{120}$

Under this approach, an out-of-state plaintiff can successfully challenge a political subdivision's adherence to a local preference statute only in those cases where the subdivision itself could successfully challenge the statute as a violation of its home rule status

124 Trojan, 916 F2d at 911 . See also Big, Country, 952 F2d at 1179 ("a state should not be penalized for exercising its power through smaller, localized units").

125 For a description and discussion of home rule provisions generally, see Antieau, 1 Municipal Corporation Law $\$ \S 3.00$ et seq (cited in note 106).

${ }^{120}$ Id $\S 3.01$. Home rule may arise in any of 3 ways: a self-executing constitutional provision which designates the authority to manage local affairs as a power inherent in localities; a statutory grant of local home rule power; or the local adoption of a home rule charter pursuant to a state constitution. Id \$\$ 3.01-3.03(1).

127 Id $\$ 3.00$.

128 See Comment, One Century of Constitutional Home Rule: A Progress Report? 64 Wash L Rev 155, 159-72 (1989) (despite constitutional and statutory provisions for home rule, Washington municipalities lack meaningful local autonomy); George D. Vaubel, Towards Principles of State Restraint Upon the Exercise of Municipal Power in Home Rule, 20 Stetson L Rev 5, 30 (1990) (legislative grant of home rule power "is almost a contradiction in terms").

${ }_{129}$ See Kenneth E. Vanlandingham, Municipal Home Rule in the United States, 10 Wm \& Mary L Rev 269, 281-83 (1968) (noting the variability of home rule laws). 
under state law. ${ }^{130}$ Moreover, if a home rule entity is properly considered an arm of the state for purposes of market participant analysis, so, too, should any other political subdivisions vested with lesser authority. The impact of local preference statutes on home rule entities thus provides a convenient test for determining whether a local preference statute should be seen as market participation, or as a form of regulation. ${ }^{131}$ Here, the home rule provisions of the states at issue in W.C.M., Trojan, and Big Country are considered in turn.

In W.C.M., Judge Posner argued that "[t]he difference between the state's preferring state residents in its own dealings and forcing local agencies to do so in theirs is both analytical and quantitative."132 Since the state had imposed a preference on "a unit of local government without any state financial support or supervision," and the bulk of public contracting takes place at the local level, ${ }^{133}$ Posner withheld market participant status.

However, Illinois law supports a different result. In People ex rel Bernardi $v$ Highland Park, ${ }^{134}$ the Illinois Supreme Court suggested that the Illinois preference statute superseded the local autonomy of home rule entities. Highland Park concerned a home rule municipality's attempt to skirt the requirements of the statewide Prevailing Wage Act. The court held that since the Act addressed "statewide" issues, "Highland Park's attempt to abrogate the prevailing wage law was an act ultra vires, being outside the grant of home rule power ...."13s Instead, "Highland Park had no choice but to comply with the statute's requirements." ${ }^{136}$ In determining that the Prevailing Wage Act was a matter of statewide concern, the Highland Park court drew an analogy to the Illinois

130 Of course, if this challenge fails, the out-of-state plaintiff might still prevail by showing the preference policy to be generically invalid. See Section III.A.

${ }^{131}$ See Doreen J. Piligian, Resident Preference Laws and the Award of Public Contracts, 10 Construc L 10 (May 1990). Piligian notes that while political subdivisions have been described as "mere creatures of the state," many are in fact governed by home rule charters. Id at 23. In such cases, Piligian asserts, local preference statutes may restrain local decisionmaking and burden local funds - a form of regulation rather than market participation. Id. However, a more detailed analysis is required since, as argued above, home rule provisions in fact provide highly variable degrees of.local autonomy.

$132730 \mathrm{~F} 2 \mathrm{~d}$ at 496.

133 Id.

134 121 III 2d 1, 15-17, 520 NE2d 316, 322-23 (1988).

135 Id at 16

136 Id at 5. 
local preference statute, which, the court found, also addressed statewide issues. ${ }^{137}$

Reconsidering W.C.M. in light of Highland Park, it appears that the Illinois Preference Act left the state's subdivisions no power to contract in any way other than in conformance with the Preference Act. In other words, the municipality acted not as an independent actor subject to an imposed preference, but rather as an arm of the state. Under this view, the Preference Act should have been upheld.

In disagreeing with W.C.M., the Trojan court relied principally on its assessment of local autonomy. Under Pennsylvania law, "the local bodies covered by the statute exist only by grace of state authority ...."138 The court saw "no reason why, attendant on making such affirmative grants of authority, the Commonwealth may not also restrict the contracting power of such local bodies."139 No basis remained to distinguish preferences imposed on central state agencies-which "certainly would be permitted"-from similar restrictions imposed on local bodies. ${ }^{140}$

Reference to Pennsylvania's home rule provisions buttresses the soundness of the Trojan court's holding. Under the Pennsylvania Constitution, "[a] municipality which has a home rule charter may exercise any power or perform any function not denied by this Constitution, by its home rule charter or by the General Assembly at any time."141 This language designates the scope of home rule authority but also permits the state legislature to control local affairs by passing acts which affect both general and local concerns. This weak form of local autonomy supports the Trojan court's readiness to view localities as simple arms of the state for purposes of the preference statute. Indeed, the court cited Pennsylvania

${ }^{137}$ Id at 14, citing Illinois Preference Act, Ill Rev Stat, ch 48 If 269 et seq (1985). The Highland Park court observed that:

Were home rule authorities allowed to govern their local labor conditions, the [Mlinois] Constitution's vision of home rule units exercising their powers to solve local problems would be corrupted and that power used to create a confederation of modern feudal estates which, to placate local economic and political expediencies, would in time destroy the General Assembly's carefully crafted and balanced economic policies. It is precisely for this reason, to avoid a chaotic and ultimately ineffective labor policy, that the State has a far more vital interest in regulating labor conditions than do local communities.

Id at 16.

${ }^{138}$ Trojan, 916 F2d at 911.

130 Id.

140 Id.

$141 \mathrm{~Pa}$ Const, Art IX, § 2. 
cases detailing the subordinate status of local subdivisions. ${ }^{142}$ In sum, the court held that the suppliers of local subdivisions were in effect "supplying for the state."143

In Big Country, the Ninth Circuit followed Trojan, holding that a state preference statute controlling the purchases of local school districts fell within the market-participant exception. ${ }^{\mathbf{1 4 4}}$ However, the Big Country court paid only cursory attention to the issue of local government law presented by the case before it. Arguing that political subdivisions "exist at the will of the state," the court chose to view them as simple arms of the state for purposes of market participant analysis. ${ }^{145}$

Notably, the Big Country court reached its holding without any reference to Alaska law. Instead, the court relied on another Ninth Circuit case dealing with California law, Trojan, and a hornbook on local government which mentioned the general rule of "complete control" by various states over their subdivisions. ${ }^{146}$ That the court was satisfied by this authority reflects its reluctance to look to Alaska law to determine the actual status of the school board. ${ }^{147}$ Yet had it done so, the Big Country court could have furnished a more robust basis for its holding.

The Alaska Constitution provides that home rule boroughs or cities "may exercise all legislative powers not prohibited by law or by charter."148 This apparently broad language is in practice tempered by the facility with which legislative powers may be removed from the cities. The Supreme Court of Alaska has held that even a broad construction of home rule powers cannot defeat the provisions of a state statute "expressly made applicable to home rule municipalities . . .."148

142 Trojan, 916 F2d at 911 n 15. For Pennsylvania law, the Trojan court rested on, for example, Department of Public Welfare $v$ Adams County, $30 \mathrm{~Pa}$ Commw 164, 373 A2d 143, $145 \mathrm{n} 4$ (1977), rev'd on other grounds $481 \mathrm{~Pa} 230,392$ A2d 692 (1977); Plum Township Annexation Case, $178 \mathrm{~Pa}$ Super 376, 116 A2d 260 (1955).

$143916 \mathrm{~F} 2 \mathrm{~d}$ at 911 .

144952 F2d at 1179.

${ }^{145}$ Id ("A state should not be penalized for exercising its power through smaller, localized units.").

${ }^{146}$ Id, citing City of Inglewood v City of Los Angeles, 451 F2d 948, 954 (9th Cir 1971); Trojan, 916 F2d at 911; Osborne M. Reynolds, Local Government Law §§ 27, 174 (1982 \& Supp 1990).

147 The Big Country court noted its reluctance to adopt a rule that would require "diffcult case-specific inquiries into the degree of subdivision autonomy." 952 F2d at 1179.

148 Alaska Const, Art X, \& 11.

14 Alaska $v$ Petersburg, 538 P2d 263, 268-69 (Alaska 1975). The statute at issue in Petersburg provided that it was "applicable to organized boroughs and political subdivisions 
Indeed, the Alaska preference statute considered in Big Country singled out schools receiving state funds, requiring that they observe a local preference when buying dairy products. ${ }^{150}$ In the face of such specificity, the school boards' autonomy and delegated power fell away, as envisioned by the Alaska constitution. Thereafter, the subdivisions in question served as arms of the state for purchasing purposes.

The disagreement among these cases is not so much a "split" on the meaning of the market participant exception, but the result of the difficulty in applying the exception. Lacking firmly-established criteria for applying the exception, the courts have adopted inconsistent approaches. By encouraging courts to give proper consideration to the inherent variations in state law, the private-party test provides a more reliable basis for evaluating local preference statutes.

Although, under the private-party test, the local preference statutes at issue in W.C.M., Trojan, and Big Country all appear valid, this does not mean that home rule provisions present no obstacle to the validity of local preference statutes. For example, the California Constitution provides that home rule municipalities shall have autonomous control over "municipal affairs." California law, "municipal affairs" include "[t]he expenditure of a city's funds on [public works] projects and the rates of pay of the workers whom it hires to carry them out," at least where such projects are not "considered to be of State concern" and do not involve the expenditure of state or federal funds. ${ }^{162}$ This conception suggests, at a minimum, that California could not impose a local preference statute on home rule entities undertaking self-financed public works projects.

\section{CoNCLUSION}

Under a private-party definition of market participation, states enjoy immunity from the dormant Commerce Clause only when acting in a manner that could legally be undertaken by a private actor in the market. Reference to private action ensures

of the state, home rule or otherwise ... ." 1972 Alaska Sess Laws ch 113, $\$ 4$ ("An Act relating to wages, hours and working arrangements").

${ }^{130}$ Alaska Stat \& 36.15.050(a) (1992).

181 Cal Const Art XI, § 5, as explained by Vial v San Diego, 122 Cal App 3d 346, 348, 175 Cal Rptr 647, 648 (1981).

${ }_{152}$ Vial v San Diego, 122 Cal App 3d at 348, citing City of Pasadena v Charleville, 215 Cal 384, 392, 10 P2d 745, 750 (1932). 
that states cannot use the exception indirectly to impose restraints on commerce which would be barred if imposed directly. At the same time, the private-party test allows states an avenue to meet the parochial demands inevitably placed upon them.

Applied to local preference statutes, the private-party model prompts two questions. First, the preference should be evaluated at a generic level. Unless a private party could have exercised such a preference, the dormant Commerce Clause must be applied. Second, state law should be examined to determine whether the state and its subdivisions can properly be considered the same actor. In this capacity, home rule provisions can provide a convenient test of subdivisions' actual level of autonomy.

Application of the private-party test demonstrates that the validity of local preference statutes under the dormant Commerce Clause depends in large part on individual states' law of local government. A state may impose a local preference if the state keeps its subdivisions reined in, but not if it has cut them a lot of slack. In turn, this conclusion implies that by amending their law of local government, states could reduce the federal constitutional obstacles to their ability to act in the market. 